\title{
Castor Bean (Ricinus communis L.) - A Biofuel Plant: Morphological and Physiological Parameters Propagated from Seeds in Bangladesh
}

\author{
Dr. Kamrun Nahar
}

Assistant Professor, Department of Environmental Science and Management, North south University, BANGLADESH

\begin{abstract} growth stages.

\section{INTRODUCTION}

C astor oil plant (Ricinus communis L.) is a non food, drought resistant, energy crop gaining attention for producing biofuel as biodiesel in developed as well as in developing countries. As an oil bearing biomass feedstock, it can ensure an alternative source of energy and reduce our dependency on fossil fuel. This plant can grow anywhere including soil considered infertile for food production.
\end{abstract}

Pot experiments were carried out in Dhaka, Bangladesh from March to September 2012 to evaluate the morphological and physiological parameters of Castor oil Plant (Ricinus communis L.), a second generation energy crop propagated from seeds. The leaves and petioles of castor plants were collected from the earthen pot to determine the leaf and petiole nutrient contents. So this study provides a reliable account of the endogenic concentrations of nutrients present in petiole and their content in leaves including the morphological parameters such as plant height, stem diameter, leaf growth, fresh and dry weight of leaves, petiole and root length of the plant at 2 vegetative growth stages grown in Silty clay loam soil were attempted. The experiment revealed that the morphological parameters responded better in mature plant compared to young plant but the physiological parameter showed variations at 2

Key words: Castor oil plant, Ricinus communis, Height, leaf, Root and Nutrient uptake.

It belongs to the family Euphorbiaceae and is one of the medicinally important oil seed crop (Kumari et al., 2008). The oil is prescribed for infestation of intestinal worms. Infusion of the leaves was used as a remedy for rash, itch and eye inflammation. The decoction of leaves is used for skin diseases, diarrhoea and kidney, urinary bladder infections (Boulos, 1983) and also may have damaging effects on animals (Akande et al., 2011). It is a non-edible drought resistant perennial oilseed crop, widely cultivated throughout tropical regions. The plant may grow upto a height of 6 to 15 feet and can leave for many years. The large, palmately lobed leaves may be over 20 inches (Khahagi, 2007). The seeds contain approximately 46- $60 \%$ oil and are the only commercial source of ricinoleic acid that is used as industrial lubricants, paints, coatings, and plastics (Caupin, 1997, Ogunniya 2006). The oil has great promises in the field of biodiesel production (Ogunniya 2006). Besides being used as a source of biodiesel, the oil can also be used for manufacturing candles, soaps and cosmetics (Deore and Johnson, 2008). The oil has also been used as a lubricant in the internal combustion engines in Airplanes (Alam et al., 2010). India is the largest producer of castor oil, representing $60 \%$ of the global production followed by China and Brazil (FAO, 2006). Production of castor plants has increased since the middle of the twentieth century (Rajarathinam and Parmar 2001).
The Plant is produced from seed as well as by tissue culture. Regeneration by tissue culture technique would also be a feasible alternative for improving the quality and production of castor oil plant. In vitro propagation or tissue culture therefore can be used to produce a large number of plants that are genetically identical to parent plant as well as to one another (Raven et al., 1999, Nahar et al., 2012).

Castor plant is a sustainable source of second generation biodiesel feedstock species and the overall supply can be increased with different propagation technologies. In addition, the plant can grow in drought as well as in flooding condition and the land use patterns in Bangladesh are suitable for its cultivation. Present investigation was undertaken to study some of the physiological and morphological parameters of castor plant propagated from seeds and grown in earthen pot with silty clay loam soil.

\section{Materials and Methods}

The experiments were carried out with Castor plant at author's roof top garden, Dhaka, Bangladesh. Seeds were sown in poly bags having size of $21 \times 11 \mathrm{~cm}$ and germinated after 7-10 days. Poly bags were filled with mixed soil and well decomposed farm yard manure in equal proportion in ratio of 1:1:1. The drainage holes were provided at the bottom of the polybags.

2 weeks seedlings were transplanted in $25 \mathrm{~cm}$ height and 30 com diameter clay pots. The pots were filled with silty clay loam soil. The field capacity of the soil was $33 \%$. The soil was air dried and sieved through a $2 \mathrm{~mm}$ sieve for chemical and other analyses. 
The general characteristics of the soil were: Sand $-5.8 \%$, Silt- $60.2 \%$, clay-34.0\%, Maximum water holding capacity46\%, Hygroscopic moisture-1.40\%, Porosity-49\%, Bulk Density-1.27g/cc, Particle Density - 2.57g/cc, PH 7.2, EC143uS, OM - 1.14, CEC - 17.9 meq/100g soil andc N $0.06 \%$. The experiments were arranged to get all the plants
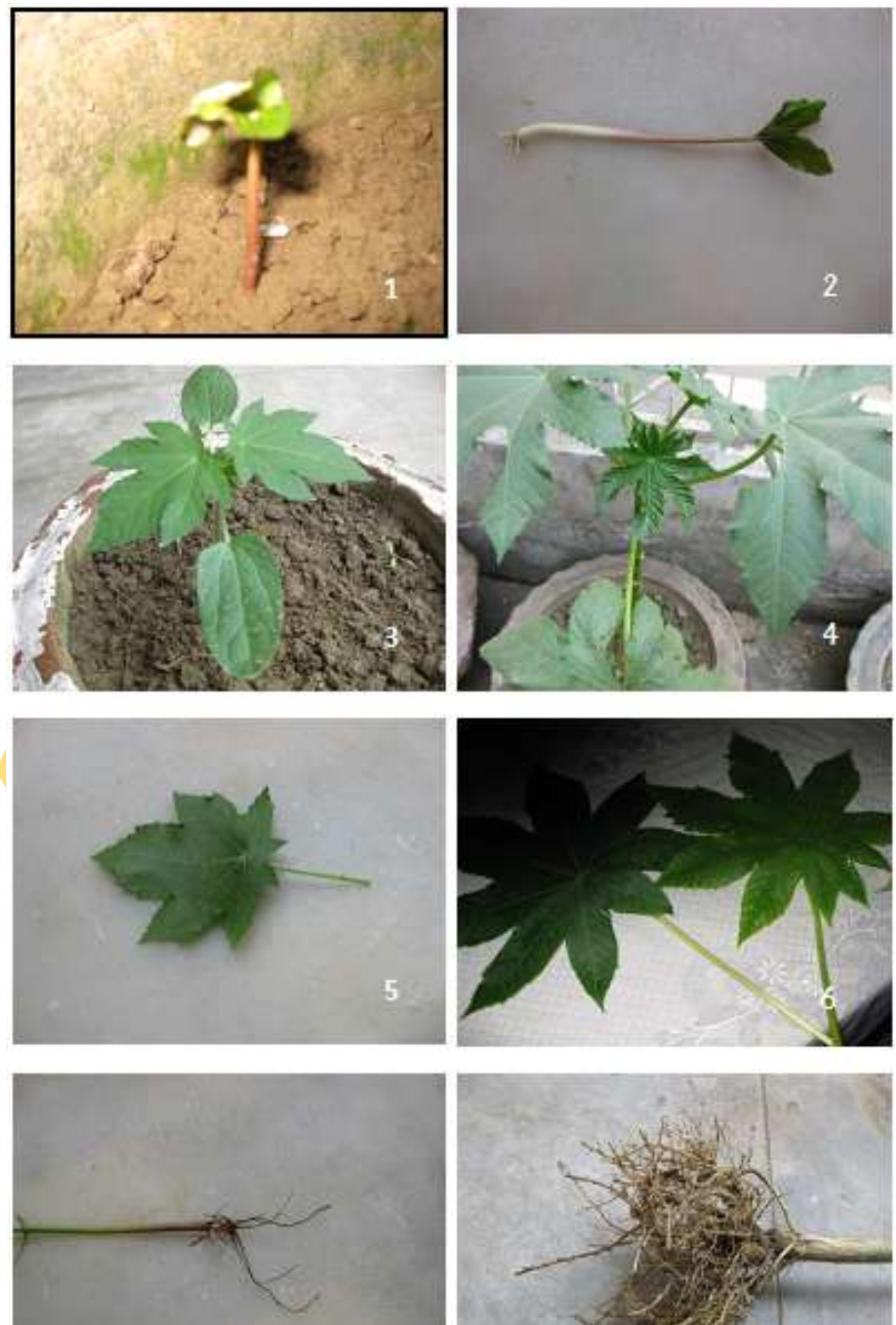

Plate 1: 8 days old seedling of castor Plate 2: 12 days old seedling Plate 3: 4 weeks old seedling Plate 4: 6 months old plant in the pots with sufficient sunlight. Nutrient supply, water supply and other intercultural operations were done as and when necessary. Collection of petiole and leaves were done at 4 weeks and 6 months after transplanting. Other morphological data and physiological parameters at this two vegetative growth stages were also recorded.
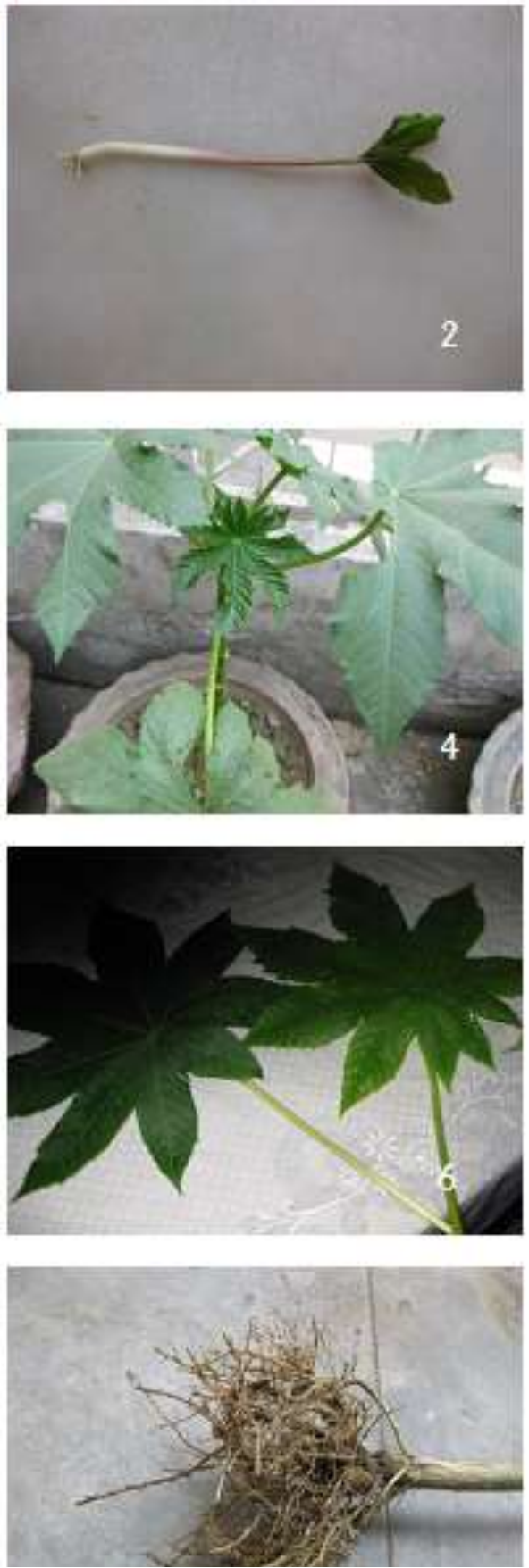

Plate 5: Leaf with petiole of 4 weeks old castor Plant Plate 6: Leaves with petiole of 6 months old plant Plate 7: Roots of 4 weeks castor seedling Plate 8: Roots of 6 months old plant 


\section{RESULTS}

In the present study, the height and other morphological and physiological parameters of 4 weeks and 6 months of the plants were recorded. Results revealed that all the morphological parameter responded better in mature 6 months old plant compared to 4 weeks young plant. But the physiological parameters like nutrient content showed variation at two growth stages. The percentage of Nitrogen and Sulphur were higher in 6 months old leaves but the concentration of potassium and phosphorus was lower compared to 4 weeks old leaves. But in case of petiole the percentage of all the nutrients were lower in mature plant except the Potassium content compared to young plant.

Table 1. Morphological parameters of 4 weeks and 6 months old Castor oil plant

\begin{tabular}{|c|c|c|c|c|c|c|c|c|c|c|c|}
\hline $\begin{array}{c}\text { Castor } \\
\text { oil } \\
\text { Plant }\end{array}$ & $\begin{array}{c}\text { Plant } \\
\text { height } \\
(\mathrm{cm})\end{array}$ & $\begin{array}{c}\text { Stem } \\
\text { diameter } \\
(\mathrm{cm})\end{array}$ & $\begin{array}{c}\text { Leaf } \\
\text { fresh } \\
\mathrm{wt}(\mathrm{gm})\end{array}$ & $\begin{array}{c}\text { Petiole } \\
\text { fresh } \\
\mathrm{wt}(\mathrm{gm})\end{array}$ & $\begin{array}{c}\text { Leaf dry } \\
\mathrm{wt}(\mathrm{gm})\end{array}$ & $\begin{array}{c}\text { Petiole } \\
\text { dry wt } \\
(\mathrm{gm})\end{array}$ & $\begin{array}{c}\text { Petiole } \\
\text { length } \\
(\mathrm{cm})\end{array}$ & $\begin{array}{c}\text { Leaf } \\
\text { length } \\
(\mathrm{cm})\end{array}$ & $\begin{array}{c}\text { Leaf } \\
\text { Width } \\
(\mathrm{cm})\end{array}$ & $\begin{array}{c}\text { Root } \\
\text { Length } \\
(\mathrm{cm})\end{array}$ & $\begin{array}{c}\text { Root/ } \\
\text { shoot } \\
\text { ratio }\end{array}$ \\
\hline 4 weeks & 15 & 0.3 & 2.01 & 1.42 & 0.45 & 0.012 & 5.53 & 6.50 & 5.53 & 7.00 & 0.47 \\
\hline 6 months & 72.0 & 1.3 & 6.84 & 2.31 & 1.30 & 0.27 & 22 & 32 & 31 & 21 & 0.29 \\
\hline
\end{tabular}

Table 2. Physiological parameters of 4 weeks old castor plant

\begin{tabular}{|c|c|c|c|c|c|}
\hline Samples & $\% \mathrm{~N}$ & $\%$ Crude protein & $\% \mathrm{P}$ & $\% \mathrm{~K}$ & $\% \mathrm{~S}$ \\
\hline & & & & & \\
Castor Leaf & 0.98 & 6.10 & 0.30 & 0.36 & 0.23 \\
\hline Castor Petiole & 0.14 & 0.88 & 0.37 & 0.77 & 0.12 \\
\hline
\end{tabular}

Table 3. Physiological parameter of 6 months Castor oil plant

\begin{tabular}{|c|c|c|c|c|c|}
\hline & & & & & \\
Samples & $\%$ N & \% Crude protein & $\%$ P & $\%$ K & $\%$ S \\
\hline Castor Leaf & 1.30 & 8.12 & 0.22 & 0.34 & 0.43 \\
\hline Castor Petiole & 0.27 & 1.69 & 0.36 & 0.75 & 0.20 \\
\hline
\end{tabular}

\section{Discussion}

Vegetative growth and other physiological parameter of castor oil seedling showed that based on the measurement and analysis of the above-ground part of the seedlings at two growth stages in the pots, it is concluded that 6 months old plant has higher growth, crude protein and nutrient concentrations especially nitrogen and sulphur compared to 4 weeks old seedling as it is not welldeveloped but the root, shoot ratio of the young seedling was higher compared to the mature plant. In conclusion mature plant shows better morphological parameters excluding the root/shoot ratio but shows lower concentration in some of the physiological parameters.

\section{ACKNOWLEDGEMENT}

Authors wish to thank Dr. Sirajul Haque for providing the necessary laboratory facilities at the Department of Soil, Water and Environment, University of Dhaka, Bangladesh.

\section{REFERENCES}

Akande, T.O., A.A. Odunsi and O.S. Adedeji, 2011. Toxicity and nutritive assessment of castor (Ricinus communis) and processed cake in rat diet. Asian J. Anim. Sci., 5: 330-339.

Alam, I., S.A.Sharing, S.C. Mondal, J. Alam, M, Khalekuzzaman, M. Anisuzzaman and M.F. Alam, 2010. In vitro micro propagation through cotyledonary node culture of castor bean (Ricinus Communis L.) Aust. J. Crop Sci, 4: 81-84.

Boulos, L. 1983. Medicinal plants of North Africa. Algonoc, Michigan Reference Publications, Inc USA.

Caupin H.J (1997) Products from castor oil: Past, present, and future. In: Gunstone FD and Padley FB (eds.) Lipid technologies and applications. Marcel Dekker, New York, pp. 787-795

Deore A.J, Johnson TS (2008) High frequency plant regeneration from leaf-disc cultures of Jatropha curcas L.: an important biodiesel crop. Plant Biotechnol Rep 2:7-11

Food and Agriculture Organization. online http://faostat.fao.org 2006 (Accessed on 06 November 2007)

K. Nahar and R.S. Borna, 2012. In vitro Propagation from Shoot tip Explants of Castor oil plant (Ricinus communis L): A Bioenergy Plant, Canadian Journal on Scientific and Industrial Research. 3 (5):354-355.

Kafagi, I.K. 2007. Variation of callus induction and active metabolic accumulation in callus cultures of two varieties of (Ricinus communis L.) Biotechnology 6: 193- 201.

Kumari K.G, Ganesan M, Jayabalan N (2008) Somatic organogenesis and plant regeneration in Ricinus communis. Biol Plantarum 52:17-25

Ogunniyi, D.S. 2006. Castor Oil: A vital Industrial raw material. Biosource technology, 97:1086-1091.

Rajarathinam, A. and R. S. Parmar. 2001. Application of Parametric and Nonparametric Regression Models for Area, Production and Productivity Trends of Castor (Ricinus communis L.) Crop. Asian Journal of Applied Sciences. 4 (1): 42 - 52, 2011

$$
\text { --0-- }
$$

